\title{
INVESTIGASI ALIRAN PADA THRUSTER ROV (REMOTELY OPERATED VEHICLE) MENGGUNAKAN METODE CFD
}

\author{
Kevin Raynaldo ${ }^{1}$, Steven Darmawan ${ }^{1 *}$, Agus Halim ${ }^{1}$ \\ ${ }^{1}$ Program Studi Teknik Mesin, Fakultas Teknik, Universitas Tarumanagara \\ *Email: Stevend@ft.untar.ac.id
}

Masuk: 02-12-2020, revisi: 23-09-2021, diterima untuk diterbitkan: 06-10-2021

\begin{abstract}
ABSTRAK
Remotely Operated Vehicle (ROV) merupakan sebuah underwater robot yang didesain oleh Tim Robotik UNTAR dan telah berkompetisi dalam Singapore Robotics Games (SRG) 2020. Evaluasi yang dilakukan terhadap hasil kompetisi tersebut adalah terdapat kebutuhan untuk melakukan optimasi dalam thrust dan kemampuan bermanuver sehingga ROV dapat bergerak lebih fleksibel dan stabil. Berdasarkan permasalahan tersebut, investigasi pada konfigurasi thruster dengan penambahan kort nozzle terhadap existing propeller diimplementasikan untuk meningkatkan thrust dan unjuk kerja. Pertimbangan dalam penggunaan open water characteristics sebagai dasar analisis diuraikan dalam investigasi ini. Existing propeller memiliki 3 buah blade dengan diameter $35 \mathrm{~mm}$; pitch diameter ratio sebesar 1,4; dan expanded blade area ratio sebesar 0,511 yang mana digunakan sebagai thruster ROV 2020. Investigasi tersebut menggunakan pendekatan CFD dalam software ANSYS CFX 2020 R1 dengan metode moving reference frame (MRF). Sementara itu, computational mesh menggunakan jenis general mesh atau unstructured mesh arrangements dengan total 165.201 nodes. MRF mengimplementasikan konsep frozen rotor sebagai frame change/mixing untuk mengamati aliran fluida. CFD dilakukan dengan menggunakan model shear stress transport (SST) k-omega. Simulasi tersebut dilakukan pada $300 \mathrm{rpm}$ dan $J=0,473$ sebagai operating condition ROV. Hasil simulasi menunjukkan bahwa thruster yang dilengkapi kort nozzle mampu meningkatkan thrust sebesar 2,253\% dan mengurangi torsi yang dibutuhkan propeller sebesar 6,633\%. Lebih lanjut, konfigurasi ini juga dapat mengurangi fenomena wake sebagai akibat dari putaran propeller yang mana merepresentasikan peluang manuver yang lebih baik.
\end{abstract}

Kata Kunci: ROV; kort nozzle; open water characteristics; CFD; unjuk kerja

\begin{abstract}
Remotely Operated Vehicle (ROV) is an underwater robot that designed by UNTAR Robotics Team and has been competed in Singapore Robotics Games (SRG) 2020. Evaluation that conducted from the competition is the need of optimization in thrust and maneuverability so it can move more flexible and stable. Based on the problem, investigation of thruster's configuration by adding kort nozzle to existing propeller is implemented to increase thrust and performance. Consideration in using open water characteristics for analysis is elaborated in this investigation. The existing propeller has 3-blade with $35 \mathrm{~mm}$ diameter; 1,4 pitch diameter ratio; and 0,511 expanded blade area ratio which is used as thruster of ROV 2020. It utilizes CFD approach in ANSYS CFX 2020 RI software with moving reference frame (MRF) method. Meanwhile, general mesh or unstructured mesh arrangements is used as computational mesh with 165.201 nodes. The MRF implements frozen rotor concept as frame change/mixing to observe fluid flow. The CFD with shear stress transport (SST) $k$-omega model is conducted. The simulation is done at $300 \mathrm{rpm}$ and $J=0,473$ for ROV's operating condition. The result shows that thruster equipped by kort nozzle is able to increase the thrust for 2,253\% and reduce the propeller required torque for $6,633 \%$. Furthermore, the configuration can also reduce wake phenomenon as result of rotating propeller which represents better maneuver chance.
\end{abstract}

Keywords: ROV; kort nozzle; open water characteristics; CFD; performance 


\section{PENDAHULUAN}

Salah satu model pengembangan teknologi yang dipersiapkan Tim Robotik Universitas Tarumanagara (UNTAR) untuk kompetisi robotik mendatang adalah underwater robot berjenis ROV (Remotely Operated Vehicle). Underwater robot merupakan sebuah prototype robot yang memiliki andil penting dalam keamanan pelabuhan, eksplorasi angkatan laut, keperluan sains, dan bahkan perawatan kebersihan bawah air (SRG2020, 2019). Melalui kompetisi underwater robot ini, mahasiswa sebagai calon engineer dapat memberikan usulan inovasi melalui pendekatan engineering ke dalam pengembangan ROV, khususnya terhadap existing model ROV yang telah dilombakan pada Singapore Robotic Games (SRG) 2020.

Berdasarkan hasil evaluasi terhadap ROV karya Tim Robotik UNTAR pada SRG 2020, masih terdapat unsur yang perlu dioptimasi khususnya dalam peningkatan thrust maupun kemampuan bermanuver sehingga menjadi lebih baik dan stabil melalui konfigurasi propeller yang digunakan (Abidin et al., 2015; Bahatmaka et al., 2016, 2017). Propeller pada ROV akan memiliki unjuk kerja yang lebih baik apabila dapat menghasilkan thrust dan power yang lebih tinggi pada putaran yang lebih rendah (Christ \& Wernli, 2013).

Mengacu pada keadaan tersebut, optimasi dilakukan terhadap model thruster dengan mengaplikasikan konsep desain propeller kapal atau marine sesungguhnya. Lebih lanjut, analisis optimasi didasarkan pada aplikasi kort nozzle dengan konfigurasi yang tepat untuk meningkatkan thrust propeller (Bahatmaka et al., 2016; Gerr, 2001). Kemudian, optimasi tersebut akan dianalisis dengan pendekatan CFD (Computational Fluid Dynamics) yang mana melalui pendekatan ini, gambaran mengenai distribusi tekanan dan aliran fluida dapat diperoleh (Abidin et al., 2015; Bahatmaka et al., 2016, 2017; Muljowidodo et al., 2009; Pan et al., 2019; Rahman, 2016).

Analisis konfigurasi thruster untuk menghasilkan thrust optimum dilakukan dalam batasan tertentu, yang meliputi objek analisis berupa propeller 3-blade yang digunakan pada ROV 2020 yang mana memiliki diameter blade sebesar $35 \mathrm{~mm}$; pitch diameter ratio sebesar 1,4 dan expanded blade area ratio sebesar 0,511. Lebih lanjut, simulasi dilakukan pada putaran $300 \mathrm{rpm}$ dengan advance coefficient sebesar 0,473 dan pendekatan CFD dilakukan pada kondisi steadystate tipe turbulent SST k-omega.

Tujuan dalam penelitian ini adalah untuk mengetahui perbedaan unjuk kerja dari penggunaan kort nozzle dan tanpa kort nozzle pada existing propeller sehingga diperoleh konfigurasi yang memiliki thrust optimum. Lebih lanjut, penelitian juga diarahkan untuk mendapatkan pengaruh nilai torsi dari masing-masing konfigurasi tersebut. Dengan demikian, output dari penelitian ini adalah penyajian konfigurasi thruster dengan thrust optimum sebagai referensi bagi Tim Robotik UNTAR khususnya dalam perancangan model thruster ROV 2021 untuk mengikuti kompetisi SRG 2021.

\section{METODOLOGI PENELITIAN}

Metode penelitian yang digunakan adalah metode numerik menggunakan software simulasi CFD ANSYS CFX 2020 R1 dengan pendekatan metode volume hingga (Abidin et al., 2015; Bahatmaka et al., 2016, 2017; Muljowidodo et al., 2009; Pan et al., 2019; Rahman, 2016; Versteeg \& Malalasekera, 2007). Adapun flowchart metode penelitian dapat dilihat pada Gambar 1. 

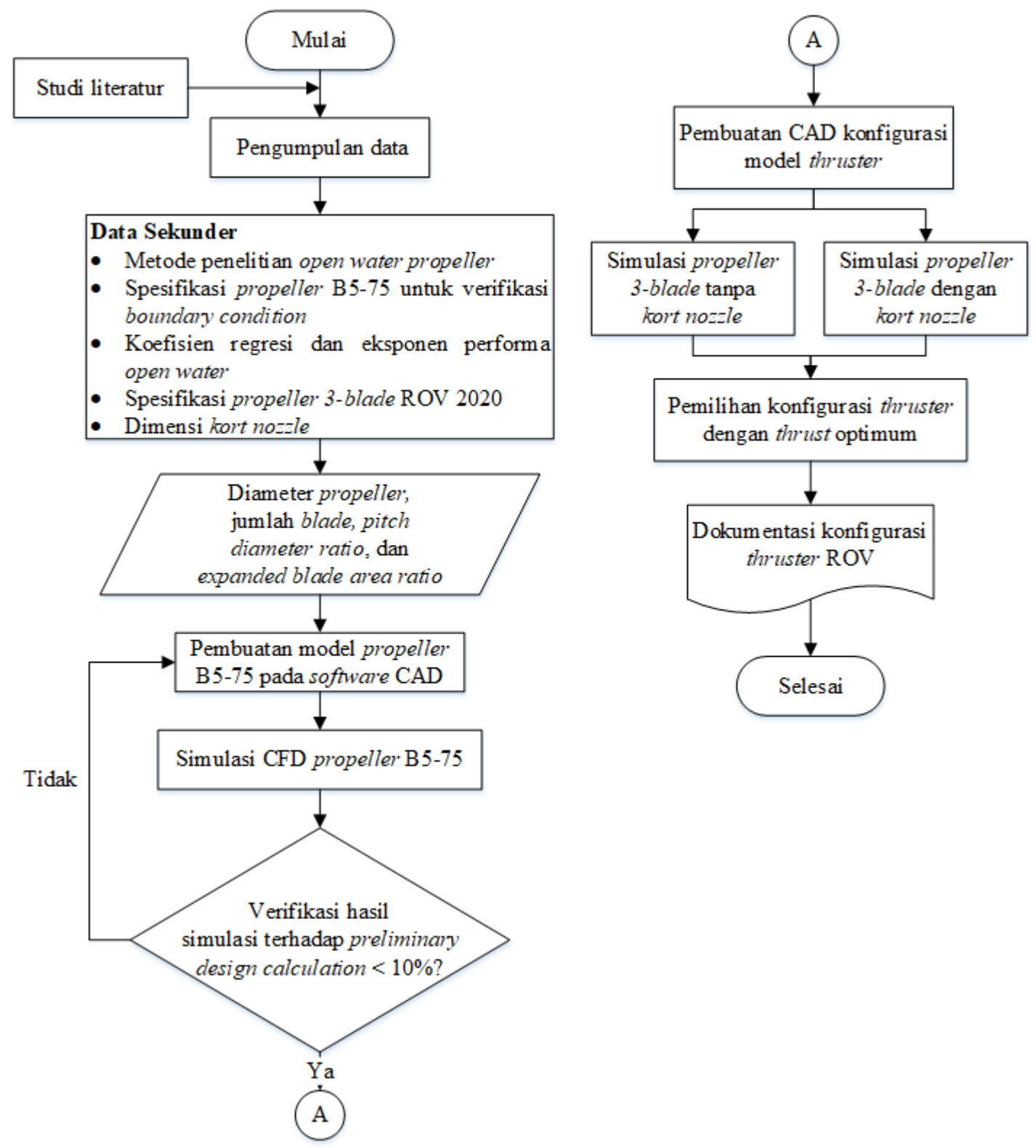

Gambar 1. Flowchart metode penelitian

Penelitian ini menggunakan preliminary design calculation atau perhitungan teoritis untuk memverifikasikan boundary condition dalam proses simulasi dengan menggunakan sebuah sampel propeller B5-75 yang diperoleh dari peneliti sebelumnya (Bahatmaka et al., 2016). Dengan terverifikasinya boundary condition propeller tersebut, maka pemodelan simulasi yang sama dapat diaplikasikan terhadap konfigurasi model thruster yang dianalisis. Melalui pemodelan tersebut, maka dapat dipilih konfigurasi thruster yang memiliki thrust paling optimum. Adapun metode pendekatan CFD yang digunakan adalah Moving Reference Frame (MRF) dengan model boundary condition sesuai Gambar 2, yang mana pengaturan didasarkan pada diameter terluar objek analisis (Bahatmaka et al., 2016, 2017; Joung et al., 2014; Majdfar et al., 2017; Voerman, 2012; Zhang et al., 2020). 


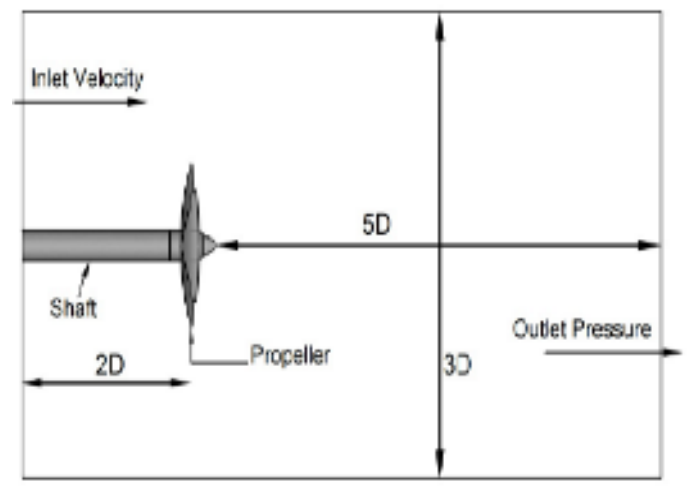

Gambar 2. Boundary condition of open water propeller

(Bahatmaka et al., 2016, 2017)

Metode MRF yang diterapkan menggunakan konsep frozen rotor pada frame change/mixing pemodelan CFD. Lebih lanjut, terdapat dua domain utama dalam MRF ini, yaitu stationary domain yang meliputi fluida di sekitar propeller dan rotating domain yang meliputi propeller dengan ukuran mesh yang lebih kecil dibandingkan stationary domain (Joung et al., 2014; Majdfar et al., 2017; Voerman, 2012; Zhang et al., 2020). Perbedaan ukuran mesh dimaksudkan untuk mendapatkan komputasi yang lebih teliti meskipun membutuhkan waktu yang lebih lama (Darmawan \& Tanujaya, 2019). Lebih lanjut, tipe shear stress transport (SST) k-omega dipilih sebagai pemodelan analisis turbulen dalam penelitian ini (Joung et al., 2014; Majdfar et al., 2017). Hasil penelitian ini dapat dijadikan dasar penelitian selanjutnya dengan melakukan komparasi antara eksperimen dan simulasi untuk menciptakan data yang saling berhubungan (Irawan et al., 2017).

\section{Desain ROV}

Desain existing model ROV yang digunakan dalam Underwater Robot Competition-SRG 2020 dapat disajikan pada Gambar 3, sementara spesifikasi utama ROV tersebut disajikan pada Tabel 1.

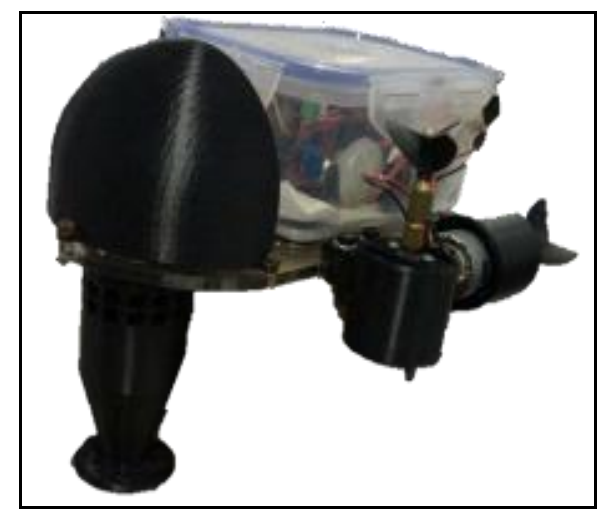

Gambar 3. Existing model ROV 2020

Tabel 1. Spesifikasi utama existing model ROV 2020

\begin{tabular}{lc}
\hline \multicolumn{1}{c}{ Dimensi } & Nilai \\
\hline Massa total dengan komponen di udara & $1,5 \mathrm{~kg}$ \\
Berat total dengan komponen di udara & $14,715 \mathrm{~N}$ \\
\hline
\end{tabular}




\section{Konfigurasi Model Thruster}

Konfigurasi model thruster yang dianalisis meliputi aplikasi kort nozzle pada propeller, yang mana jenis kort nozzle yang digunakan adalah Shushkin nozzle tipe C (Schneekluth \& Bertram, 1998). Lebih lanjut, clearance yang ditetapkan pada kort nozzle antara blade tip dengan dinding dalam kort nozzle adalah 1\% dari diameter propeller (Caldas et al., n.d.; Majdfar et al., 2017). Desain CAD konfigurasi propeller tersebut dibuat dalam software Autodesk Inventor 2020 yang disajikan pada Gambar 4 dan Gambar 5, sementara spesifikasi utama propeller diuraikan pada Tabel 2.

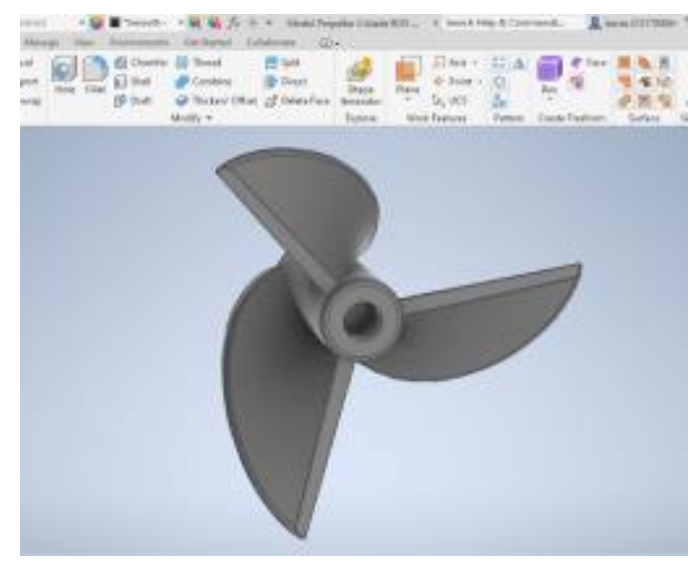

Gambar 4. Propeller 3-blade tanpa kort nozzle Gambar 5. Propeller 3-blade dengan kort nozzle

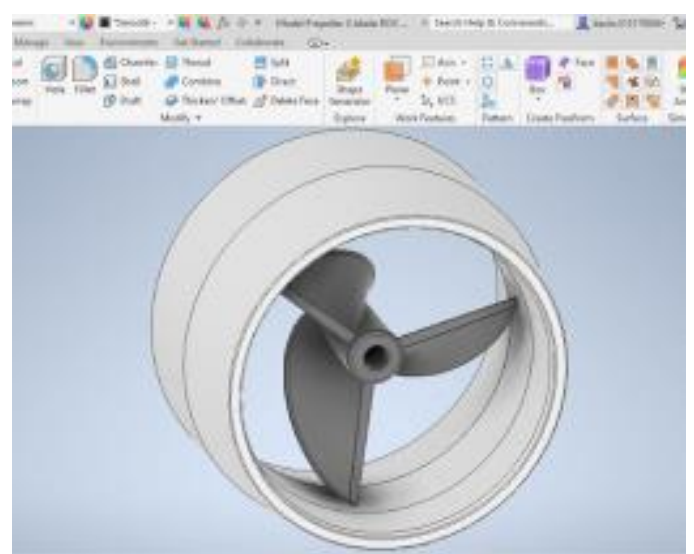

Tabel 2. Spesifikasi utama propeller 3-blade (Arduinouno, n.d.)

\begin{tabular}{lc}
\hline \multicolumn{1}{c}{ Spesifikasi } & Nilai \\
\hline Pitch diameter ratio $(P / D)$ & 1,4 \\
Diameter blade $(D)$ & $35 \mathrm{~mm}$ \\
Clearance pada tip & $0,35 \mathrm{~mm}$ \\
Expanded blade area ratio $\left(A_{E} / A_{0}\right)$ & 0,511 \\
Outline & custom \\
\hline
\end{tabular}

\section{Verifikasi Boundary Condition}

Verifikasi boundary condition untuk simulasi thrust dan torsi propeller didasarkan pada perhitungan teoritis atau preliminary design calculation. Preliminary design calculation tersebut hanya dapat diaplikasikan pada propeller outline B-series untuk $\operatorname{Re}<2 \times 10^{6}$ (Gaafary et al., 2011; Oosterveld \& van Oossanen, 1975). Oleh karena adanya keterbatasan dalam kecocokan perhitungan tersebut, maka diambil spesifikasi propeller dari peneliti sebelumnya yang menggunakan konsep preliminary design calculation. Adapun propeller tersebut berjenis B5-75 (Propeller outline B-series sejumlah 5-blade dengan expanded blade area ratio 0,75$)$ dan dengan pitch diameter ratio 0,6 serta advance coefficient diasumsikan sebesar 0,15 (Bahatmaka et al., 2016).

Preliminary design calculation tersebut menggunakan persamaan thrust coefficient $\left(K_{T}\right)$ dan torque coefficient $\left(K_{Q}\right)$ sebagai fungsi jumlah blade $(z)$, expanded blade area ratio $\left(A_{E} / A_{0}\right)$, pitch diameter ratio (P/D), dan advance coefficient (J) (Bahatmaka et al., 2016, 2017; Gaafary et al., 2011; Oosterveld \& van Oossanen, 1975). 


$$
\begin{aligned}
& K_{T}=\sum_{n=1}^{39}\left(C_{T_{n}}\right)\left(J^{S n}\right)\left(\frac{P}{D}\right)^{t n}\left(\frac{A_{E}}{A_{0}}\right)^{U n}\left(Z^{v n}\right) \\
& K_{Q}=\sum_{n=1}^{47}\left(C_{Q_{n}}\right)\left(J^{S n}\right)\left(\frac{P}{D}\right)^{t n}\left(\frac{A_{E}}{A_{0}}\right)^{U n}\left(Z^{v n}\right)
\end{aligned}
$$

dimana $C_{T n}$ dan $C_{Q n}$ berturut-turut adalah koefisien regresi terhadap thrust dan torsi, sementara itu $S_{n}, t_{n}, U_{n}$, dan $v_{n}$ berturut-turut adalah eksponen terhadap $J, P / D, A_{E} / A_{0}$, dan $Z$. Adapun nilai koefisien regresi dan eksponen yang terdapat pada persamaan (1) dan (2) telah ditabelkan dalam (Oosterveld \& van Oossanen, 1975).

Setelah nilai $K_{T}$ dan $K_{Q}$ diperoleh melalui persamaan (1) dan (2), selanjutnya kedua nilai tersebut diinput-kan ke dalam persamaan (3) dan (4) untuk mendapatkan nilai thrust dalam $\mathrm{N}(T)$ dan torsi dalam $\mathrm{Nm}(Q)$ (Bahatmaka et al., 2016, 2017; Gaafary et al., 2011; Oosterveld \& van Oossanen, 1975):

$$
\begin{aligned}
& \mathrm{T}=K_{T}\left(\rho n^{2} D^{4}\right) \\
& \mathrm{Q}=K_{Q}\left(\rho n^{2} D^{5}\right)
\end{aligned}
$$

dimana $\rho$ adalah massa jenis fluida $\left(\mathrm{kg} / \mathrm{m}^{3}\right), n$ adalah putaran $(r p s)$, dan $D$ adalah diameter propeller $(m)$.

Hasil perhitungan teoritis menggunakan konsep preliminary design calculation dan hasil simulasi propeller B5-75 dapat disajikan pada Tabel 3 dan Tabel 4.

Tabel 3. Verifikasi thrust simulasi propeller B5-75 terhadap thrust teoritis

\begin{tabular}{cccc}
\hline Putaran & Thrust Teoritis & Thrust Simulasi & Penyimpangan \\
\hline $300 \mathrm{rpm}$ & $1,529 \mathrm{~N}$ & $1,419 \mathrm{~N}$ & $7,194 \%$ \\
\hline
\end{tabular}

Tabel 4. Verifikasi torsi simulasi propeller B5-75 terhadap torsi teoritis

\begin{tabular}{cccc}
\hline Putaran & Torsi Teoritis & Torsi Simulasi & Penyimpangan \\
\hline $300 \mathrm{rpm}$ & $0,0207 \mathrm{Nm}$ & $0,0212 \mathrm{Nm}$ & $2,415 \%$ \\
\hline
\end{tabular}

Berdasarkan hasil verifikasi thrust dan torsi pada Tabel 3 dan Tabel 4, nilai penyimpangan hasil simulasi terhadap perhitungan teoritis yang dapat diterima adalah kurang dari $10 \%$. Hasil verifikasi tersebut menunjukkan pada putaran $300 \mathrm{rpm}$, penyimpangan thrust dan torsi yang terjadi kurang dari $10 \%$ sehingga hasil simulasi dapat terverifikasi. Dengan demikian, boundary condition dan pemodelan simulasi pada putaran $300 \mathrm{rpm}$ sebagaimana yang juga diterapkan untuk seluruh konfigurasi model thruster dapat terverifikasi dan diaplikasikan.

\section{Mesh Dependency Analysis}

Analisis pengaruh jumlah nodes terhadap nilai thrust dan torsi hasil simulasi dilakukan untuk memilih computational mesh yang akan digunakan sebagai referensi, baik untuk rotating domain maupun stationay domain dengan pertimbangan waktu komputasi. Computational mesh yang digunakan unuk rotating domain dan stationary domain adalah jenis general mesh atau unstructured mesh arrangements yang mana secara berturut-turut dapat secure disajikan pada Gambar 6 dan Gambar 7. 


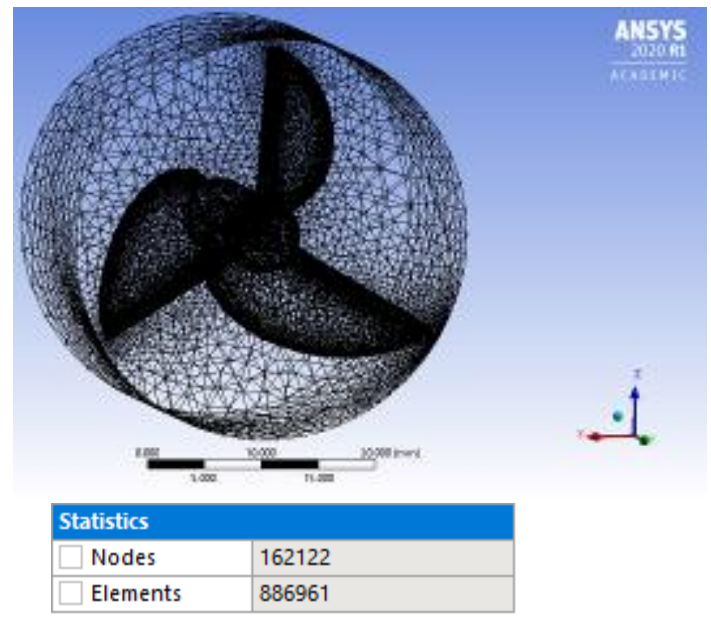

Gambar 6. Origin mesh rotating domain

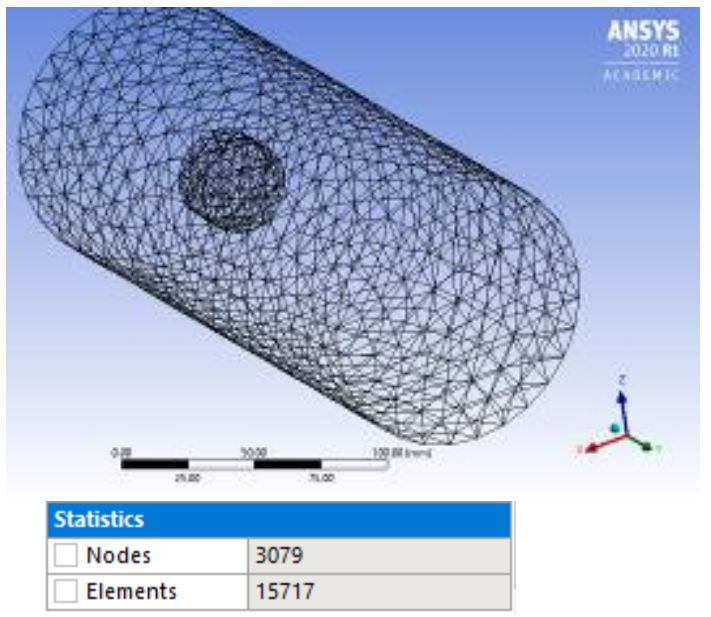

Gambar 7. Origin mesh stationary domain

Komparasi beberapa variasi computational mesh propeller 3-blade dapat disajikan pada Tabel 5 dan Tabel 6.

Tabel 5. Mesh dependency analysis nilai thrust propeller 3-blade tanpa kort nozzle

\begin{tabular}{cccc}
\hline Total Nodes & $\begin{array}{c}\text { Beda Total Nodes } \\
\text { Terhadap Origin } \\
\text { Mesh }(\%)\end{array}$ & $\begin{array}{c}\text { Thrust } \\
(\mathbf{N})\end{array}$ & $\begin{array}{c}\text { Penyimpangan Thrust } \\
\text { Terhadap Origin } \\
\text { Mesh }(\%)\end{array}$ \\
\hline 316.529 & $+91,602$ & 0,00601 & $+4,159$ \\
165.201 & & 0,00577 & \\
49.416 & $-70,087$ & 0,00464 & $-19,584$ \\
\hline
\end{tabular}

Tabel 6. Mesh dependency analysis nilai torsi propeller 3-blade tanpa kort nozzle

\begin{tabular}{cccc}
\hline Total Nodes & $\begin{array}{c}\text { Beda Total Nodes } \\
\text { Terhadap Origin } \\
\text { Mesh }(\%)\end{array}$ & $\begin{array}{c}\text { Torsi } \\
(\mathbf{N m})\end{array}$ & $\begin{array}{c}\text { Penyimpangan Torsi } \\
\text { Terhadap Origin } \\
\text { Mesh }(\%)\end{array}$ \\
\hline 316.529 & $+91,602$ & $7,856 \times 10^{-5}$ & $+1,775$ \\
165.201 & & $7,719 \times 10^{-5}$ & \\
49.416 & $-70,087$ & $6,818 \times 10^{-5}$ & $-11,672$ \\
\hline
\end{tabular}

Berdasarkan Tabel 5 dan Tabel 6, besarnya penyimpangan nilai thrust dan torsi pada mesh lebih rapat terhadap origin mesh adalah $<5 \%$. Sementara itu, besarnya penyimpangan nilai thrust dan torsi pada mesh lebih renggang terhadap origin mesh adalah $>10 \%$. Hasil ini menunjukkan bahwa penurunan jumlah nodes akan memberikan penyimpangan lebih signifikan dibandingkan dengan penambahan jumlah nodes. Jumlah nodes pada mesh lebih rapat memiliki penyimpangan nilai thrust dan torsi yang tidak signifikan terhadap jumlah nodes pada origin mesh, sehingga jumlah total nodes pada origin mesh sebanyak 165.201 nodes dengan element size sebesar $10 \mathrm{~mm}$ pada rotating domain dan $12 \mathrm{~mm}$ pada stationary domain dipilih sebagai computational mesh karena memiliki waktu komputasi yang relatif lebih singkat dibandingkan dengan mesh lebih rapat. 


\section{HASIL DAN PEMBAHASAN}

Analisis unjuk kerja konfigurasi model thruster ROV didasarkan pada nilai thrust yang dihasilkan melalui simulasi dengan software ANSYS CFX 2020 R1. Simulasi yang diaplikasikan pada konfigurasi model thruster didasarkan pada konsep boundary condition pada keadaan open water test yang telah terverifikasi terhadap perhitungan teoritis.

Hasil simulasi konfigurasi model thruster pada putaran $300 \mathrm{rpm}$ dengan $J=0,473$ sebagai operating condition thruster tersebut dapat disajikan pada Gambar 8 sampai dengan Gambar 15.

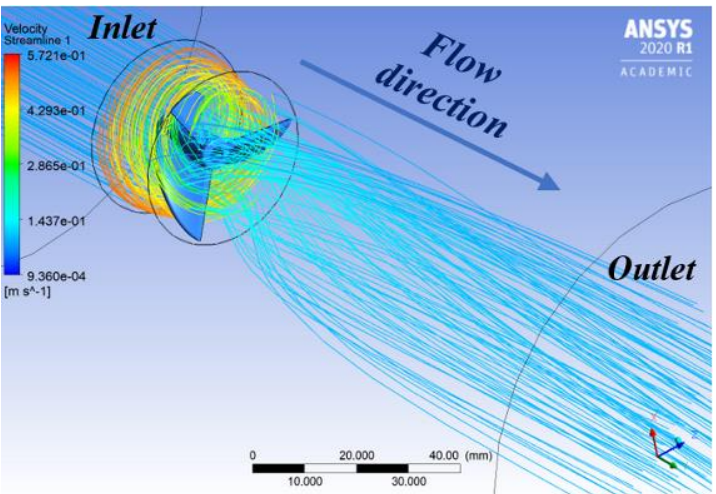

Gambar 8. Velocity streamline propeller 3blade tanpa kort nozzle

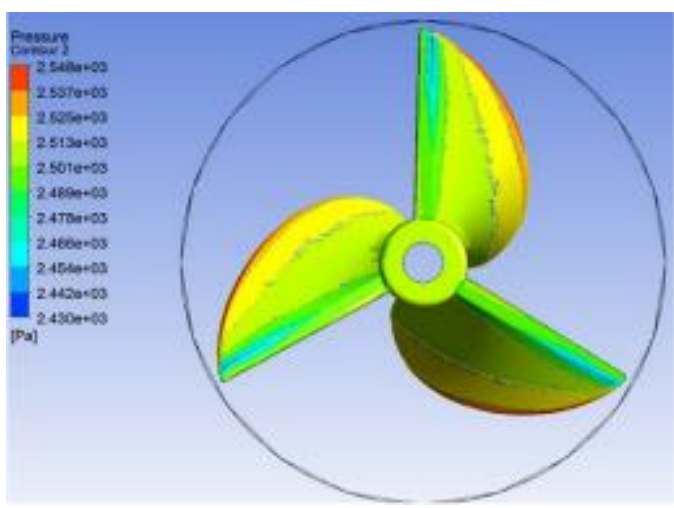

Gambar 10. Face pressure contour propeller 3-blade tanpa kort nozzle

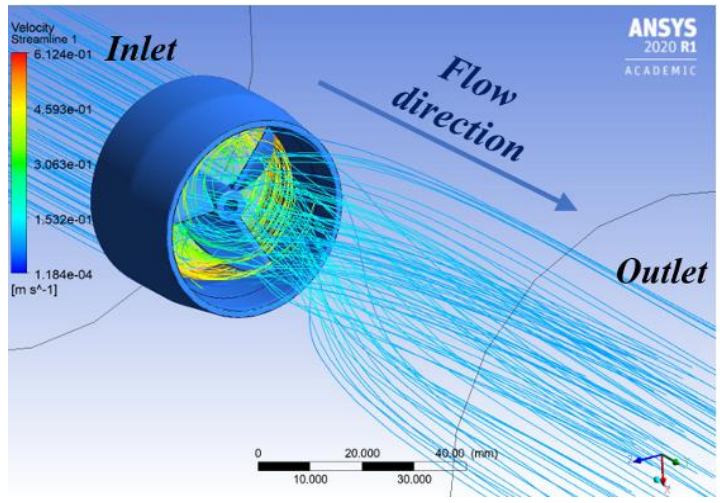

Gambar 12. Velocity streamline propeller 3-blade dengan kort nozzle

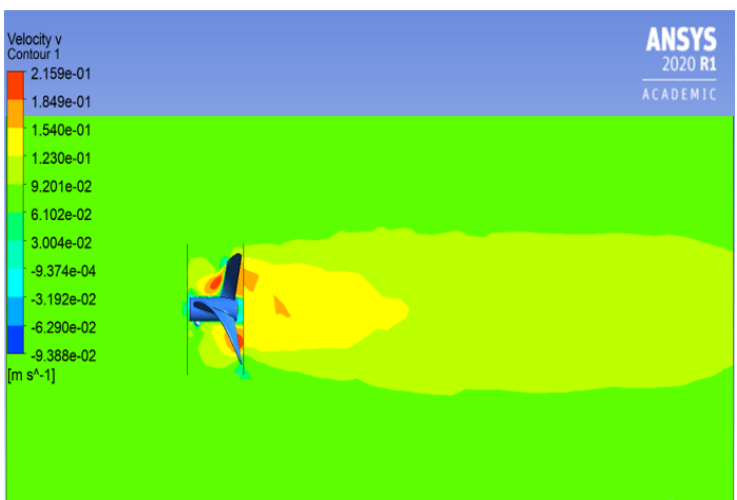

Gambar 9. Velocity v contour propeller 3blade tanpa kort nozzle

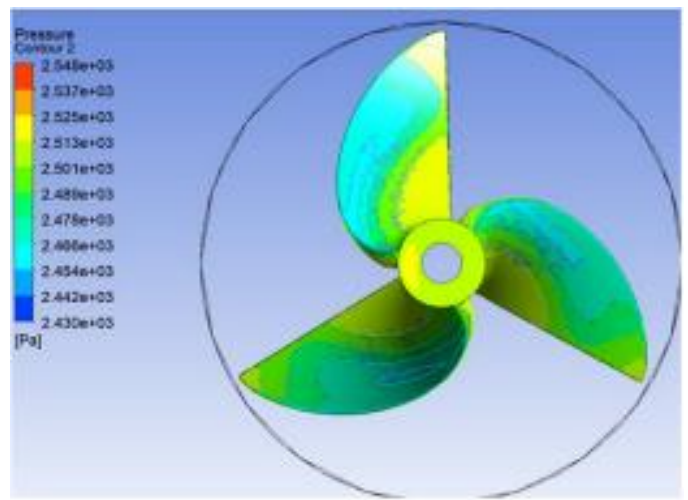

Gambar 11. Back pressure contour propeller 3-blade tanpa kort nozzle

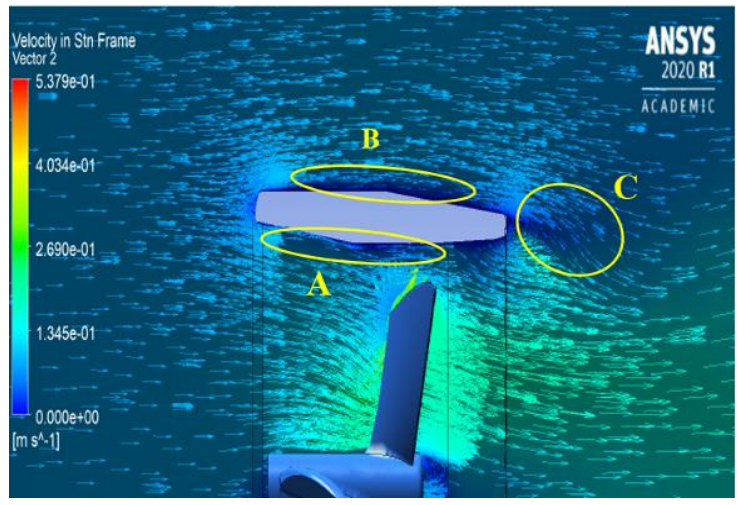

Gambar 13. Velocity in stn frame vector propeller 3-blade dengan kort nozzle 


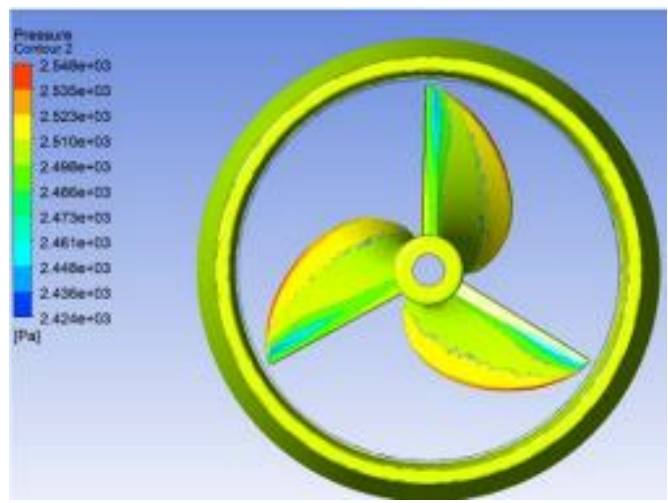

Gambar 14. Face pressure contour propeller 3-blade dengan kort nozzle

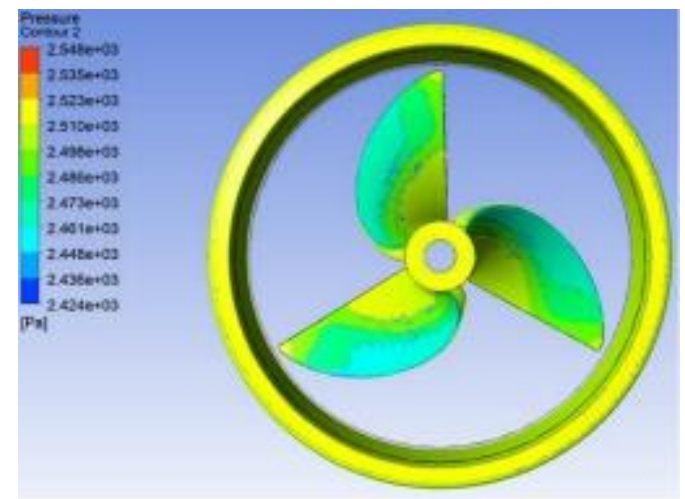

Gambar 15. Back pressure contour propeller 3-blade dengan kort nozzle

Tabel 7. Perbandingan unjuk kerja thruster 3-blade dengan kort nozzle terhadap tanpa kort nozzle

\begin{tabular}{|c|c|c|c|c|c|}
\hline \multicolumn{2}{|c|}{ Thrust (N) } & \multirow{2}{*}{$\begin{array}{l}\text { Perubahan } \\
\text { Thrust }(\%)\end{array}$} & \multicolumn{2}{|c|}{ Torsi (Nm) } & \multirow{2}{*}{$\begin{array}{c}\text { Perubahan } \\
\text { Torsi }(\%)\end{array}$} \\
\hline $\begin{array}{c}\text { Tanpa Kort } \\
\text { Nozzle }\end{array}$ & $\begin{array}{c}\text { Dengan Kort } \\
\text { Nozzle }\end{array}$ & & $\begin{array}{c}\text { Tanpa Kort } \\
\text { Nozzle }\end{array}$ & $\begin{array}{c}\text { Dengan Kort } \\
\text { Nozzle }\end{array}$ & \\
\hline 0,00577 & 0,0059 & $+2,253$ & $7,719 \times 10^{-5}$ & $7,207 \times 10^{-5}$ & $-6,633$ \\
\hline
\end{tabular}

Berdasarkan Tabel 7, aplikasi kort nozzle pada propeller 3-blade yang mana juga digunakan pada ROV 2020, dapat meningkatkan nilai thrust yang dihasilkan dan mengurangi terjadinya fenomena wake sebagai akibat dari putaran propeller terhadap body ROV. Peningkatan thrust melalui aplikasi kort nozzle adalah 2,253\%. Lebih lanjut, adanya peningkatan nilai thrust yang dihasilkan oleh propeller melalui aplikasi kort nozzle juga disajikan dalam penelitian sebelumnya yang dilakukan oleh (Bahatmaka et al., 2016) yang mana dapat ditampilkan dalam Tabel 8. Penelitian tersebut menggunakan propeller dengan spesifikasi sebagai berikut: $D=130$ $\mathrm{mm} ; P / D=0,6 ; z=5$; dan outline $=B$-series dengan analisis pada putaran $300 \mathrm{rpm}$.

Tabel 8. Hasil penelitian (Bahatmaka et al., 2016) pada nilai gaya (T) dan torsi (Q) propeller

\begin{tabular}{cccc}
\hline & Tipe Model & Gaya $(\mathbf{T}), \mathbf{N}$ & Torsi $(\mathbf{Q}), \mathbf{N m}$ \\
\hline & Propeller tanpa nozzle & 1,67 & 0,016 \\
B-Series (B5-75) & Nozzle A & 2,06 & 0,020 \\
& Nozzle B & 2,12 & 0,021 \\
& Nozzle C & 2,26 & 0,023 \\
\hline
\end{tabular}

Kemudian, adanya peningkatan thrust menggunakan kort nozzle dikarenakan terjadi akselerasi aliran air yang melewati dinding dalam kort nozzle yang ditunjukkan pada vektor kecepatan aliran yang lebih besar pada Gambar 13. Pada Gambar 13 tersebut, kecepatan aliran air di titik A (dinding dalam kort nozzle) lebih besar dibandingkan kecepatan aliran air di titik B (dinding luar kort nozzle), yang mana ditunjukkan dari warna vektor di titik A yang cenderung berwarna biru muda dibandingkan dengan warna vektor di titik $\mathrm{B}$ yang cenderung berwarna biru tua. Fenomena ini menunjukkan bahwa tekanan yang berada sepanjang streamline titik B lebih besar dibandingkan dengan tekanan yang berada sepanjang streamline titik A. Profil kort nozzle yang mempertimbangkan aspek hidrodinamika tersebut memungkinkan terjadinya akselerasi aliran air di 
bagian dinding dalam melalui perubahan luas diameter dalamnya, yang mana dilalui oleh air yang menuju propeller. Analisis visual hasil simulasi kort nozzle juga memberikan pengaruh berupa reduksi fenomena wake khususnya pada bagian tip pada blade sebagai hasil putaran propeller. Lebih lanjut, sebagai akibat dari perbedaan tekanan di titik A dan titik B, maka terjadi fenomena swirling atau pusaran air yang ditunjukkan pada vektor di titik C. Vektor aliran air tersebut bergerak dari daerah bertekanan tinggi ke daerah bertekanan lebih rendah yang menciptakan fenomena swirling. Semakin besar beda kecepatan antara titik A dan titik B, maka semakin besar pula fenomena swirling terjadi. Sementara itu, peningkatan kecepatan aliran air di titik A merepresentasikan adanya peningkatkan momentum partikel fluida yang menuju propeller, sehingga semakin banyak partikel fluida yang dapat dipindahkan oleh propeller dalam waktu yang sama. Keadaan ini sesuai dengan Hukum II Newton yang mana semakin besar momentum yang terjadi pada fluida, maka semakin besar thrust yang dihasilkan propeller.

Di sisi lain, peningkatan thrust yang relatif belum optimal, yaitu sebesar 2,253\% dinilai sebagai akibat dari operating condition dimana thruster bekerja belum mencapai titik optimal operasi ROV. Di sisi lain, aplikasi kort nozzle sebagai thruster ROV dapat menurunkan torsi yang dibutuhkan untuk memutar propeller sebesar 6,633\%. Fenomena ini sesuai dengan penelitian yang dilakukan untuk mengetahui pengaruh operating condition berdasarkan variabel $J$ terhadap thrust dan torsi propeller yang telah dilakukan oleh (Zhang et al., 2020). Mengacu pada penelitian yang telah dilakukan, maka konfigurasi model thruster yang terdiri dari propeller 3-blade dengan kort nozzle dipilih sebagai rekomendasi untuk thruster ROV 2021.

\section{KESIMPULAN}

Konfigurasi model thruster yang direkomendasikan untuk ROV 2021 adalah thruster yang terdiri dari propeller 3-blade dengan kort nozzle. Aplikasi kort nozzle pada propeller 3-blade dengan putaran $300 \mathrm{rpm}$ dapat meningkatkan nilai thrust sebesar 2,253\% dan menurunkan torsi yang dibutuhkan untuk memutar propeller sebesar 6,633\%. Sementara itu, kort nozzle juga dapat mereduksi fenomena wake putaran propeller pada bagian tip blade terhadap body ROV yang mana merepresentasikan adanya peluang kestabilan manuver yang lebih baik. Lebih lanjut, melalui penetapan operating condition yang lebih optimal khususnya dalam set up putaran propeller dapat memberikan peluang peningkatan thrust pada ROV dengan kort nozzle yang lebih baik. Besarnya thrust dipengaruhi oleh nilai koesifien advance dan putaran propeller yang mana semakin optimal putaran propeller maka semakin tinggi thrust yang dapat dihasilkan. Penelitian lebih lanjut untuk mendapatkan putaran kerja paling optimal dapat dilakukan untuk mendapatkan peningkatan thrust yang lebih baik.

\section{Ucapan Terima Kasih}

Penulis mengucapkan terima kasih kepada Program Studi Teknik Mesin Universitas Tarumanagara dan rekan-rekan dalam Tim Robotik U-ROV UNTAR yang senantiasa mendukung proses penyusunan karya ilmiah ini.

\section{REFERENSI}

Abidin, Z., Christmianto, D., \& Trimulyono, A. (2015). Analisa Underwater Thruster Pada Remotely Operated Vehiicle (Rov) Dengan Metode Cfd. Jurnal Teknik Perkapalan, 3(2).

Arduinouno. (n.d.). Boat Propeller Hole Diameter 3mm, Out Diameter $35 \mathrm{~mm}$ CCW CW Sepasang. Retrieved October 6, 2020, from https://www.tokopedia.com/ arduinouno/boatpropeller-hole-diameter-3mm-out-diameter-35mm-ccw-cw-sepasang 
Bahatmaka, A., Kim, D.-J., \& Chrismianto, D. (2016). Optimization of Ducted Propeller Design for the ROV (Remotely Operated Vehicle) Using CFD. Advances in Technology Innovation, 2(3), 73-84.

Bahatmaka, A., Kim, D. J., Chrismianto, D., Hai, N., \& Prabowo, A. R. (2017). Optimization of thrust propeller design for an ROV (Remotely Operated Vehicle) consideration by Genetic Algorithms. MATEC Web of Conferences, 138. https://doi.org/10.1051/matecconf/ 201713807003

Caldas, A., Meis, M., \& Sarasquete, A. (n.d.). CFD validation of different propeller ducts on open water condition.

Christ, R. D., \& Wernli, R. L. (2013). The ROV Manual: A User Guide for Remotely Operated Vehicles: Second Edition. In The ROV Manual: A User Guide for Remotely Operated Vehicles: Second Edition. https://doi.org/10.1016/C2011-0-07796-7

Darmawan, S., \& Tanujaya, H. (2019). CFD investigation of flow over a backward-facing step using an RNG k-E turbulence model. International Journal of Technology, 10(2), 280-289. https://doi.org/10.14716/ijtech.v10i2.800

Gaafary, M. M., El-Kilani, H. S., \& Moustafa, M. M. (2011). Optimum design of B-series marine propellers. Alexandria Engineering Journal, 50(1), 13-18. https://doi.org/ 10.1016/j.aej.2011.01.001

Gerr, D. (2001). Propeller Handbook: The Complete Reference for Choosing, Installng, and Understanding Boat Propellers. McGraw-Hill Professional.

Irawan, A. P., Halim, A., \& K., H. (2017). Hybrid robot system design. IOP Conf. Ser.: Mater. Sci. Eng. 237012006.

Joung, T. H., Choi, H. S., Jung, S. K., Sammut, K., \& He, F. (2014). Verification of CFD analysis methods for predicting the drag force and thrust power of an underwater disk robot. International Journal of Naval Architecture and Ocean Engineering, 6(2), 269-281. https://doi.org/10.2478/IJNAOE-2013-0178

Majdfar, S., Ghassemi, H., Forouzan, H., \& Ashrafi, A. (2017). Hydrodynamic prediction of the ducted propeller by CFD solver. Journal of Marine Science and Technology (Taiwan), 25(3), 268-275. https://doi.org/10.6119/JMST-016-1214-2

Muljowidodo, K., Adi N., S., Budiyono, A., \& Prayogo, N. (2009). Design of SHRIMP ROV for surveillance and mine sweeper. Indian Journal of Marine Sciences, 38(3), 332-337.

Oosterveld, M. W. C., \& van Oossanen, P. (1975). Further Computer-Analyzed Dat of the Wageningen B-Screw Series. International Shipbuilding Progress, 22(251), 251-262. https://doi.org/10.3233/isp-1975-2225102

Pan, Y. cun, Zhang, H. xin, \& Zhou, Q. dou. (2019). Numerical simulation of unsteady propeller force for a submarine in straight ahead sailing and steady diving maneuver. International Journal of Naval Architecture and Ocean Engineering, 11(2), 899-913. https://doi.org/10.1016/j.ijnaoe.2019.04.002

Rahman, D. A. D. (2016). Studi Kasus Modifikasi Daun Propeller Pada MV. Meratus Barito [Institut Teknologi Sepuluh Nopember]. http://repository.its.ac.id/51141/

Schneekluth, H., \& Bertram, V. (1998). Ship Design for Efficiency and Economy. In Ship Design for Efficiency and Economy. Butterworth Heinemann. https://doi.org/10.1016/b978-0-7506-4133-3.x5000-2

SRG2020. (2019). Underwater Robot Competitions.

Versteeg, H. K., \& Malalasekera, W. (2007). Computational Fluid Dynamics: The Finite Volume Method. In An introduction to computational fluid dynamics: the finite volume 
method: Vol. $M$ (2nd ed.). http://books.google.nl/books?id=RvBZ-UMpGzIC\&hl=nl \&source=gbs_navlinks_s

Voerman, M. (2012). Research into the effect of Counter-Rotating Propellers, for the propulsion of a Vertical Take-Off and Landing Ducted Fan UAV, n the flow pattern.

Zhang, Q., Jaiman, R. K., Ma, P., \& Liu, J. (2020). Investigation on the Performance of a Ducted Propeller in Oblique Flow. Journal of Offshore Mechanics and Arctic Engineering, 142(1). https://doi.org/10.1115/1.4043943 